ngực. Trong 83 bệnh nhân trong nghiên cứu có $38,6 \%$ trẻ có biểu hiện khó thở và rút lõm lồng ngực khi nhập viện. Nôn cũng là một triệu chứng khá thường gặp chiếm $9,6 \%$, trong đó có 1 trẻ đủ tiêu chuẩn chẩn đoán trào ngược dạ dày thực quản.

Số lượng bạch cầu ưa acid trung bình của kiểu hình khò khè khởi phát muộn cao hơn so với kiểu hình khò khè khởi phát sớm $(0,33$ so với $0,22)$, tuy nhiên sự khác biệt này không có ý nghĩa thống kê với $p=0,7416$. Về xét nghiệm vi sinh, RSV test nhanh được thực hiện trên 68 bênh nhân, đây là virus thường găp nhất gây khò khè ở trẻ nhỏ. Kiểu hình khò khè khởi phát sớm có tỷ lệ RSV dương tính cao nhất $27,1 \%$, kiểu hình khò khè khởi phát trung gian có tỷ lế RSV dương tính là $12,5 \%$. Cãy dịch ty hầu được thực hiện trên 51 bệnh nhân với tỷ lệ dương tính là $41,1 \%$, trong đó những vi khuẩn thường gặp nhất là Streptococcus pneumoniae, Moraxella catarrhalis, Haemophilus influenza.

\section{KẾT LUÂNN}

Viêm tiểu phế quản và hen phế quản là 2 nguyên nhân thường gặp nhất gây khò khè ở trẻ dưới 5 tuổi, trong đó viềm tiểu phế quản chủ yếu gặp ở trẻ dưới 2 tuổi và thường là kiểu hình khè khò khởi phát sớm. Số đợt khò khè trung bình của 3 kiểu hình khò khè khác biệt rõ rệt. Kiểu hình khò khè khởi phát muộn thường là khò khè tái đi tái lại và đa số được chẩn đoán là hen phế quản.

Lời cảm ơn. Chúng tôi xin chân thành cảm ơn bệnh nhi và gia đình trẻ đã tham gia, hợp tác tốt trong quá trình nghiên cứu. Xin cảm ơn Bệnh viện đa khoa Tâm Anh và đặc biệt là khoa Nhi đã tạo điều kiện thuận lợi để nhóm nghiên cứu có thể thu thập số liệu và hoàn thành nghiên cứu.

\section{TÀI LIỆ THAM KHẢO}

1. Martinez FD, Wright AL, Taussig LM, Holberg CJ, Halonen $\mathbf{M}$, Morgan WJ. Asthma and Wheezing in the First Six Years of Life. N Engl J Med. 1995;332(3):133-138.

2. Al-Shamrani A, Bagais $K$, Alenazi A, Alqwaiee M, Al-Harbi AS. Wheezing in children: Approaches to diagnosis and management. Int J Pediatr Adolesc Med. 2019;6(2):68-73.

3. Patra S, Singh V, Kumar P, Chandra J, Dutta A, Tripathi M. Demographic and Clinical Profile of Children Under Two Years of Age with Recurrent Wheezing. 2011;21:3.

4. Rosa AM, Jacobson Lda S, Botelho C, Ignotti E. Prevalence of wheezing and associated factors in children under 5 years of age in Cuiabá, Mato Grosso State, Brazil. Cad Saude Publica. 2013 Sep;29(9):1816-28.

5. Stein RT, Martinez FD. Asthma phenotypes in childhood: lessons from an epidemiological approach. Paediatr Respir Rev. 2004 Jun;5(2):155-61

6. Nguyê̂n Thị Hà (2013). Nghiên cứu nguyên nhân và đăc điểm lâm sàng theo nguyên nhân gây khò khè tái diến và/hoặc dai dẳng ở trẻ dưới 5 tuổi. Trường Đai học Y Hà Nối

7. Guilbert TW, Morgan Wj, Zeiger RS et al. Atopic characteristics of children with recurrent wheezing at high risk for the development of childhood asthma. J Allergy Clin Immunol. 2004 Dec;114(6):1282-7.

8. Nguyến Thị Hiên (2015). Nghiên cứu ñguyên nhân khò khè ở trẻ dưới 5 tuổi tại khoa Miễn dịch - Dị ứng khớp bệnh viện Nhi Trung Ương. Trường Đại học Y Hà Nội.

\title{
ĐÁNH GIÁ KẾT QUẢ PHẪU THUÂTT ĐIỀU TRI UNG THƯ ĐẠI TRÀNG SIGMA
}

\section{TÓM TẮT}

Mục tiêu nghiên cứu: Đánh giá kết quả phẫu thuật điều trị ung thư đại tràng sigma tại bệnh viện $\mathrm{K}$ từ 10/2015 đến tháng 7/2016. Đối tượng và phương pháp nghiên cứu: Nghiên cứu mô tả cắt ngang, hồi cứu kết hợp tiến cứu trên55 bệnh nhân ung thư đại tràng sigma được phẫu thuât tại bênh viên $\mathrm{K}$ tù̀ 10/2015-7/2016. Kết quả: Phẫu thuật mở chiếm

\footnotetext{
${ }^{1}$ Trường Đại học Y Hà Nội

${ }^{2}$ Bềnh viện $K$

Chịu trách nhiệm chính: Trịnh Lê Huy

Email: trinhlehuy@hmu.edu.vn

Ngày nhận bài: 2.6.2021

Ngày phản biên khoa hoc: 19.7.2021

Ngày duyệt bài: 2.8.2021
}

\section{Trịnh Lê Huy ${ }^{1}$, Mai Tiến Đạt ${ }^{2}$}

$81.8 \%$, nội soi chiếm $18.2 \%$. Thời gian phẫu thuật trung bình chung là 128 phút, giữa mổ nọi soi và mổ mở không có sự khác biệt. Số lượng máu mất trung bình là $115 \mathrm{ml}$, mổ nôi soi mất ít máu hơn mổ mở. Thời gian có trung tiện trở lại trung bình 3.26 ngày, của mổ nội soi có thời gian ngẳn hơn so với của mổ mở. Thời gian hậu phẫu trung bình là 10.28 ngày, mổ nội soi có thời gian ngắn hơn so với mổ mở. Mổ nội soi và mổ mở không có khác biệt về số lượng hạch trung bình vét được và tỷ lệ vét được từ 12 hạch trở lên. Kết luận: Phẫu thuật nội soi cho thấy hiệu quả phấu thuật cũng như độ an toàn tương đương mổ mở trong khi cải thiện chất lượng çuộc sống và giảm nguy cơ một số biến chứng sau mổ nên cần được áp dụng rộng rãi cho bệnh nhân ung thư đại tràngsigma.

Tư khóa: Ung thư đại tràng Sigma, phẫu thuật. 


\section{SUMMARY \\ EFFICACY RESULTS OF SURGICAL TREATMENT IN PATIENTS WITH SIGMOID COLON CANCER}

Objective: To evaluate efficacy surgical treatment in patients with sigmoid colon cancer. Patients and method: Restropective and prospective description study of 55 patients who underwent a hand-assisted laparoscopic anterior resection or a conventional open anterior resection during 10/2015-7/2016.Results: Open surgery accounts for $81.8 \%$, endoscopy accounts for $18.2 \%$. Overall surgical time was 128 minutes, there was no significant differences between laparoscopic surgery and open surgery. The first flatus time is 3.26 days, the laparoscopic is shorter than that of open surgery. The durations of hospital stay is 10.28 days and laparoscopic is shorter. Our metaanalysis suggests that laparoscopic surgery could achieve the same effectiveness with open surgery in relation to lymph node harvested. Conclusions: The patients with sigmoid colon cancer who underwent a laparoscopic surgery for sigmoid cancer had a lower incidence of postoperative leukocytosis, less administration of pain killers than those who underwent open surgery. Clinical outcomes for patients' recovery and pathology status were similar between the two groups. Therefore, a laparoscopic surgery for sigmoid colon cancer is feasible.

Key words: Sigmoid colon cancer, surgery

\section{I. ĐẶT VẤN ĐỀ}

Ung thư đại trực tràng là ung thư phổ biến đứng thứ 3 về tỷ lệ mắc ở cả hai giới, đứng thứ 2 về tỷ lệ tử vong. Theo SEER năm 2014 có khoảng 136.830 trường hợp ung thư đại trực tràng mới mắc trong đó 50.310 trường hợp tử vong ${ }^{1}$. Tại Việt Nam, theo số liêu năm 2010 trên cả nước có khoảng 5.434 người mới mắc đứng hàng thứ 4 ở cả hai giới.

Đại tràng sigma là đoạn cuối của đại tràng trái, nối phần cuối của đại tràng xuống với trực tràng. Đại tràng Sigma cũng là nơi hay gặp ung thư nhất trong toàn khung đại tràng, chiếm tỷ lệ khoảng $25-35 \%$ ung thư đại trực tràng tùy theo các báo cáo khác nhauu $2,3,4$. Phẫu thuật (PT) là phương pháp điều trị chính trong ung thư đại trực tràng nói chung. Hiện tại các nghiên cứu về đánh giá kết quả phẫu thuậtung thư đại tràng Sigma tai Viêt Nam còn ít nên chúng tôi tiến hành nghiên cứu "Đánh giá kêt quả phẫu thuật điều trị ung thư đại tràng Sigmatại bệnh viện $K$ từ 10/2015 đến tháng 7/2016"

\section{II. ĐỐI TƯƠNG VÀ PHƯƠNG PHÁP NGHIÊN CỨU}

2.1. Thời gian và địa điểm:Gồm 55 bênh nhân (BN) ung thưđại tràng (UTĐT) sigma nguyên phát được điều trị phẩu thuật tại bệnh viện từ 10/2015 đến 07/2016.

\section{2. Đối tượng nghiên cứu}

2.2.1. Tiêu chuẩn chọn bệnh nhân nghiên cứu:

- Được chẩn đoán là ung thư đại tràng sigma xác định trong khi phẫu thuật. Kết quả giải phẫu bệnh là ung thư biểu mô.

- Được phẫu thuật cắt đoạn đại tràng

- Có hồ sơ lưu trữ đây đủ, biên bản phẫu thuật chi tiết, có mô tả tổn thương đầy đủ

- Có thông tin sau điêu trị

- Chấp nhận tham gia nghiên cứu

\subsubsection{Tiểu chuẩn loại trừ:}

-Thể mô bênh học không phải ung thư biểu mô

-Bênh nhân có chống chỉ định với phẫu thuật

- Bểnh nhân bỏ điều tri

- Không có hồ sơ lưu trữ đầy đủ

-Không có thông tin sau điều trị

2.3. Cỡ mấu: lấy mẫu thuận tiện

2.4. Phương pháp nghiên cứu: Nghiên cứu mô tả hồi cứu có theo dõi dọc

\subsection{Cách thức tiến hành:}

- Thu thập hồ sơ bệnh án theo mẫu bệnh án

- Chọn bệnh nhân đủ tiêu chuẩn vào nghiên cứu

- Ghi nhận các triệu chứng lâm sàng và cận lâm sàng trước khi điều trị.

- BN được điều trị bằng phẫu thuật cắt đoạn đại tràng sigma cả bằng phương pháp $\mathrm{PT}$ mở hoặc PT nội soi.

\subsection{Phân tích số liêu:}

- Thu thập các số liệu dựa trên mẫu bệnh án nghiên cứu.

- Số liệu nghiên cứu được mã hoá, nhập, xử lý và phân tích trên máy tính, sử dụng phần mềm SPSS 16.0 .

\section{7. Đạo đức nghiên cứu:}

- Việc tiến hành nghiên cứu có xin phép và được sự đồng ý của lãnh đạo Bệnh viện $\mathrm{K}$ và gia đình bệnh nhân.

- Thông tin về tình trạng bệnh và thông tin cá nhân khác của bệnh nhân được giữ bí mật.

- Các thông tin thu được của đối tượng chỉ nhằm mục đích nghiên cứu.

\section{KẾT QUẢ NGHIÊN CỨU}

\section{1 Đặc điểm đối tượng nghiên cứu}

Trong tổng số 55 bênh nhân nghiên cứu có 29 bệnh nhân nam chiếm $52.7 \%$ và 26 bệnh nhân nữ chiếm $47.3 \%$. Tuổi trung bình là 60.3 tuổi. Nhóm từ 50-69 tuổi chiếm tỷ lệ cao nhất $60 \%$. Tỷ lệ Nam/Nữ là 1.12. 94.5\% BN đến viện khi có triệu chứng lâm sàng. Đại tiện nhày máu hay gặp nhất chiếm $90.9 \%$, đau bụng chiếm $87.3 \%$, rối loạn tiêu hóa chiếm $83.6 \%$. Hội chứng Koegnig gặp ở $18.2 \%$, gầy sút cân chiếm 
tỷ lệ 9.1\%. (bảng 1)

Bảng 1. Triệu chứng cơ năng

\begin{tabular}{|c|c|c|c|}
\hline \multicolumn{2}{|c|}{ Triệu chứng cơ năng } & Tân số & $\mathbf{\%}$ \\
\hline \multicolumn{2}{|c|}{ Đau bụng } & 48 & 87.3 \\
\hline \multicolumn{2}{|c|}{ Đại tiện nhày máu } & 50 & 90.9 \\
\hline \multirow{2}{*}{$\begin{array}{c}\text { Rối loạn } \\
\text { tiêu hóa }\end{array}$} & Táo bón & 34 & 61.8 \\
\cline { 2 - 4 } & Táo, lỏng & 12 & 21.8 \\
\hline \multicolumn{2}{|c|}{ Hội chứng Koegnig } & 10 & 18.2 \\
\hline \multicolumn{2}{|c|}{ Gầy sút cân } & 5 & 9.1 \\
\hline \multicolumn{2}{|c|}{ Không triệu chứng } & 3 & 5.5 \\
\hline \multicolumn{2}{|c|}{ Triệu chứng khác } & 0 & 0 \\
\hline
\end{tabular}

3.2. Kết quả phẫu thuật điêuu trị ung thư đại tràng Sigma

Tỷ lệ mổ nội soi là $18.2 \%$, mổ mở là $81.8 \%$. Thời gian PT ngắn nhất là 75 phút, dài nhất là 180 phút. Thời gian phẫu thuật trung bình của mổ nội soi là 125 phút, của mổ mở là 130 phút, cả hai nhóm là 128 phút. (Bảng 2)Số lượng máu mất trong mổ từ 70-250ml. Số lượng máu mất trung bình của nhóm mổ nội soi là $95 \mathrm{ml}$, của nhóm mổ mở là $124 \mathrm{ml}$, chung cả hai nhóm là $115 \mathrm{ml}$

Bảng 2. Thời gian phẫu thuật

\begin{tabular}{|c|c|c|c|}
\hline $\begin{array}{c}\text { Thời gian phẩu } \\
\text { thuật (phút) }\end{array}$ & $\begin{array}{c}\text { Ngắn } \\
\text { nhất }\end{array}$ & $\begin{array}{c}\text { Dài } \\
\text { nhất }\end{array}$ & $\begin{array}{c}\text { Trung } \\
\text { bình }\end{array}$ \\
\hline Phâ̂u thuật nội soi & 90 & 150 & $125 \pm 20$ \\
\hline Phấu thuật mở & 75 & 180 & $130 \pm 45$ \\
\hline
\end{tabular}

\begin{tabular}{|c|c|c|c|c|}
\hline \multirow{2}{*}{$\begin{array}{l}\text { Thời gian trung } \\
\text { tiện trở lại sau } \\
\text { phấu thuật }\end{array}$} & \multicolumn{2}{|c|}{ PT nội soi } & \multicolumn{2}{|c|}{ PT mở } \\
\hline & $\begin{array}{l}\text { Tân } \\
\text { số }\end{array}$ & $\%$ & $\begin{array}{l}\text { Tân } \\
\text { số }\end{array}$ & $\%$ \\
\hline$\leq 2$ ngày & 4 & 40 & 3 & 6.7 \\
\hline Từ 2- 4 ngày & 6 & 60 & 38 & 84.4 \\
\hline Trên 4 ngày & 0 & 0 & 4 & 8.9 \\
\hline Trung bình & \multicolumn{2}{|c|}{$\begin{array}{c}2.71 \pm 0.49 \\
\text { ngày }\end{array}$} & \multicolumn{2}{|c|}{$\begin{array}{c}3.36 \pm \\
0.54 \text { ngày }\end{array}$} \\
\hline $\bar{n}$ & $26 \pm 0$ & $8 \mathrm{ng}$ & & \\
\hline
\end{tabular}

Sau mố, bệnh nhân có trung tiện sở lại sớm nhất là sau 1.5 ngày, muộn nhất là 5 ngày. Trung bình chung là $3.26 \pm 0.58$ ngày. Thời gian trung tiện trở lại trung bình của nhóm BN được PT nội soi là 2.71 \pm 0.49 ngày; của nhóm PT mở là $3.36 \pm 0.54$ ngày. (Bảng 3). Thời gian hậu phẫu ngắn nhất của cả 2 nhóm là 8 ngày, dài nhất là 16 ngày, trung bình chung là $10.28 \pm 3.42$ ngày.Thời gian hậu phẫu trung bình của PT nội soi là 8.57 ngày, của PT mở là 11.61 ngày.

Về kết quả nạo vét hạch, số hạch trung bình của tất cả bệnh nhân là 12.2 hạch.Số hạch vét được của PT nội soi từ 6-2, trung bình là 11.7. Số hạch vét được của PT mở từ 6-29 hạch, trung bình 12.8 .

\section{BÀN LUẬN}

Trong nghiên cứu của chúng tôi, bệnh nhân cao tuổi nhất là 84 tuổi và bệnh nhân trẻ tuổi nhất là 28 tuổi. Kết quả này cho thấy ung thư đại tràng Sigma có thể xuất hiện ở lứa tuổi rất trẻ cho tới cao tuổi, kết quả của chúng tôi tương tự như các tác giả trên. Khi so sánh với các tác giả khác trong nghiên cứu ung thư đại trực tràng nói chung, cũng cho kết quả tương tự $5,6,7$. Cho thây là ung thư đại tràng có thể gặp ở những lứa tuối rất trẻ.

Về hình thức phẫu thuật, có 45BN (81.8\%) được mổ mở, 10BN (18.2\%) được mổ nội soi. Kết quả của chúng tôi tương đồng với tác giả Nguyên Văn Xuyên khi nghiên cứu trên 69BN ung thư ĐT Sigma tỷ lệ mổ mở là $80.6 \%$, tỷ lệ mổ nội soi là $19.4 \%{ }^{8}$. Mổ nội soi là một tiến bộ lớn của y học hiện đại, và ngày càng được áp dụng rộng rãi trong nhiều chuyên nghành. Mổ nội soi có ưu điểm là bệnh nhân phục hồi sau mổ nhanh hơn, ít đau, ít nhiễm trùng vết mổ và tính thẩm mỹ cao hơn trong khi hiệu quả điều tri

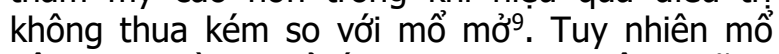
nội soi thường chỉ áp dụng được trên những bệnh nhân thuận lợi, và chưa thể thay thế hoàn toàn cho mổ mở.

Thời gian phẫu thuật trong nghiên cứu của chúng tôi ngắn nhất là 75 phút cho trường hợp cắt đoạn ĐT Sigma mổ mở và dài nhất là 180 phút cho một trường hợp cắt đoạn ĐT Sigma mở rộng kèm cắt khối di căn gan. Thời gian phẫu thuật trung bình của nhóm mổ nội soi là 125 phút, của nhóm mổ mở là 130 phút. Kết quả này của chúng tôi tương đồng với các tác giả khác Nguyễn Văn Xuyên, Sang Eun Nam, Koji Yasuda ${ }^{8}$. Số lượng máu mất trong nghiên cứu của chúng tôi thấp nhất là $70 \mathrm{ml}$ cho mổ nội soi cắt đoạn ĐT và lớn nhất là mổ mở cắt đoạn ĐT mở rộng kèm cắt khối di căn gan là $250 \mathrm{ml}$ do cầm máu diện cắt gan khó khăn. Lượng máu mất trung bình của mổ nội soi là $95 \mathrm{mi}$ tương tự so với các tác giả Kim Min Sung $88 \mathrm{ml}$, KoJi Yasuda $100 \mathrm{ml}$, Jin Tung Liang $84.5 \mathrm{ml}$. Trong nghiên cứu của chúng tôi các bệnh nhân trung tiện trở lại sau phẫu thuật sớm nhất là sau 1.5 ngày và muộn nhất là sau 5 ngày. Thời gian có trung tiện trở lại chung cho cả hai nhóm PT nội soi và PT mơ là $3.26 \pm 0.58$ ngày. Kết quả của chúng tôi cũng tương tự của tác giả Sang Eun Nam (2013) thời gian có trung tiện lần đâu là 3.4 ngày. Thời gian hậu phẫu trong nghiên cứu của chúng tôi ngắn nhất là 8 ngày cho mổ nội soi và dài nhất là 18 ngày cho trường hợp bệnh nhân mổ mở có biến chứng rò miệng nối khu trú nhưng không phải 
mổ lại. Thời gian hậu phẫu trung bình chung trong nghiên cứu của chúng tôi là 10.28 ngày. Kết quả này tương tự với tác giả Sang Eun Nam (2013). Kết quả của chúng tôi cho thấy số lượng hạch nạo vét được thấp hơn so với các tác giả nước ngoài. Như theo Jin Tung Liang (2008) sô hạch vét được trung bình là 14.4. Kết quả trên có thể giải thích do trong nghiên cứu của chúng tôi có một số bệnh nhân không được nạo vét hạch điển hình như bệnh nhân giai đoạn IV, bệnh nhân tắc ruột, già yếu bệnh kèm theo nặng không cho phép kéo dài cuộc mổ, đồng thời các tác giả nước ngoài có phương tiện làm tiêu mõ mạc treo để thu thập hạch dễ hơn.

\section{KẾT LUÂN}

Phẫu thuật là phương pháp điều trị chính trong ung thư đại trực tràng nói chung. Phẫu thuật nội soi cho thây hiệu quả phẫu thuật cũng như độ an toàn tương đương mổ mở trong khi cải thiển chất lượng cuộc sống và giảm nguy cơ một số biến chứng sau mổ nên cần được áp dụng rộng rãi cho bệnh nhân UTĐT Sigma.

TÀl LIẸU THAM KHẢO
1. SEER (2014), SEER stat Fact Sheets: Colon and Rectum.

2. Nguyễn Văn Lê (2008), "Đánh giá kết quả phẫu thuật nội soi điểu trị ung thư đại tràng tại bệnh viện Việt Đức từ 2003-2008", tr. 51.

3. A. I. Ṕhipps, A. T. Chan, S. Ogino. Anatomic subsite of primary colorectal cancer and subsequent risk and distribution of second cancers. Cancer2013;119(17):3140-3147.

4. C. M. Wray, A. Ziogas, M. W. Hinojosa, et al. Tumor subsite location within the colon is prognostic for survival after colon cancer diagnosis. Dis Colon Rectum 2009;52(8):1359-1366.

5. Nguyễn Xuân Hùng (2002), Kết quả điều trị ung thư đại tràng tại bệnh viện Việt Đức trong 5 năm (1994-1998), Tạp chí y học thực hành, 11, 15-17.

6. Trịnh Hồng Sớn (1995), Nhânn xét về chẩn đoán và điêuu trị 359 trương hợp ung thư đại tràng được mố tai bệnh viên Viêt Đức trong 8 năm(19861993), Tạp chí y học thực hành, 3, 25-27.

7. Chu Văn Đức (2010), Nghiên cứu đă̆c điểm lâm sàng, cận lâm sàng của ung thư đại tràng, Tạp chí y học thực hành, 5(715), 20-25.

8. Nguyến Văn Xuyên (2010) Kết quả điều trị ung thư đại tràng Sigma bằng phâuu thuật triệt để qua 68 trường hợp tai Bệnh viện 103, Tạp chí y dược học quân sự, 7(32), 102-108.

9. K. M. Lin, 'D. M. Ota.Laparoscopic colectomy for cancer: an oncologic feasible option.Surg Oncol 2000;9(3):127-34.

\title{
NGHIÊN CỨU BƯỚC ĐẦU VỀ CAGPAI, OIPA, DUPA CỦA HELICOBACTER PYLORI Ở BỆNH NHÂN LOÉT TÁ TRÀNG TẠI VIỆT NAM
}

\author{
Vũ Văn Khiên', Đoàn Vũ Nam², Nguyễn Quang Duật ${ }^{2}$, \\ Phạm Hồng Khánh ${ }^{2}$, Trần Thị Huyền Trang ${ }^{1}$
}

\section{TÓM TẮT}

Đăt vấn đề: Từ năm 1994, WHO đã xếp H.pylori nằm trong nhóm I gây UTDD. Tuy nhiên, khả năng gây bênh của $H$. pylori phụ thuộc vào yếu tố độc lực của nó. Đề tài nghiên cứu về tỷ lệ cagPAI, oipA, dupA ở bệnh nhân loét tá tràng tại Việt Nam. Đối tượng và phương pháp: 43 bệnh nhân loét tá tràng được chẩn đoán xác định trên nội soi và mô bênh học. CagPAI, oipA, dupA được thực hiện bằng kỹ thuật PCR. Kết quả: Tuổi hay gặp (31-59 tuổi): 60,5\%. Tỷ lệ nam/nữ: 1,5. Các triệu chứng hay gặp trong loét tá tràng gồm: Đau thượng vị, ợ hơi và ợ chua. Số bệnh nhân có 01 ổ loét: $88,4 \%$. Tỷ lê cagPAI, oipA, dupA dương tính ở bệnh nhân loét tá tràng chiếm tỳ lệ tương ứng: $62,8 \%, 9,3 \%, 65,1 \%$. Số bênh nhân có 2 gen kết hợp (cagPAI + dupA) là: 19/34 (55,9\%).

\footnotetext{
${ }^{1}$ Bệnh viện TWQD 108

2Bệnh viện 103 -Học viện Quân Y

Chịu trách nhiệm chính: Vũ Văn Khiên

Email: vuvankhien108@yahoo.com.vn

Ngày nhận bài: 7.6.2021

Ngày phản biên khoa hoc: 23.7.2021

Ngày duyệt bài: 6.8.2021
}

Kết luân: Gen oipA của $H$. pylori là yếu tố nguy cơ cao gây loét tá tràng tại Việt Nam. Cần nghiên cứu trên số lượng nhiêu hơn

Tư khóa: Helicobacter pylori, loét tá tràng, ung thư dạ dày, viêm dạ dày mạn.

\section{SUMMARY \\ INITIAL STUDY ON CAGPAI, OIPA, DUPA OF HELICOBACTER PYLORI IN DUODENAL ULCER PATIENTS IN VIETNAM}

Introduction: Since 1994, WHO has classified H.pylori in group I causing gastric cancer. However, the pathogenicity of $\mathrm{H}$. pylori is highly dependent on its virulence factor. Research topic on the rate of cagPAI, oipA, dupA in duodenal ulcer patients in Vietnam. Patients and mehods: 43 patients with duodenal ulcer were confirmed on endoscopy and histopathology. CagPAI, oipA, dupA were performed by PCR. Results: Common age (31-59 years old): $60.5 \%$. Male/Female ratio: 1.5 . Common symptoms of duodenal ulcer include: epigastric pain, belching and heartburn. Number of patients with 01 ulcer: $88.4 \%$. The rate of positive cagPAI, oipA, dupA in duodenal ulcer patients were $62.8 \%, 9.3 \%, 65.1 \%$, respectively. Number of patients with 2 combined 